\title{
Utilization of Surplus Labor in the Economy of Bangladesh
}

\author{
S M Sazid Raihan, Md. Rabiul Islam Rabi, S M Saleh Reza,
}

\begin{abstract}
Labor surplus in an economy can be a useful resource for development and future growth if it can be channeled through appropriate sectors and industries. Empirical evidence suggests that most of the countries that have successfully attained rapid economic development in last few decades, had done so through channeling their labor surplus mainly through both industrial and service sectors while putting a comparatively lower emphasis on the agricultural sector. However, due to difference in the economic infrastructure in different countries, the same method to utilize labor surplus may not be applicable universally. Rather being a highly agro-based country, Bangladesh may have to utilize its agricultural sector more to attain economic growth and labor surplus while looking for alternative sources such as agrobased and labor-intensive manufacturing and semi-skilled migration abroad. Bangladesh would also need to address the inefficiency of employment survey programs currently practiced in the country to get a clearer picture of the overall condition of employability and productivity in the economy. Investing in the labor intensive industries can be a great way for Bangladesh to take and sustain the growth rate of GDP to double figure, and well-established ready-made garment industry is a perfect example of that. A major area where the policymakers should now put their attention is to invest in the skill development of the human resource of the country, which could increase the remittance earning by manifold. Moreover, to create sufficient employment opportunities for all of the surplus labor force, there must be sustained GDP growth rate of 6.5 percent per annum, and this could only happen through increasing the participation of industrial and service sectors in the GDP growth rate.
\end{abstract}

Keywords-labor surplus, unemployment, economic growth, human resource development, underemployment.

\section{Introduction}

In most of the economic development models where labor surplus is present, it is often widely prescribed by experts to channel the surplus labor through attaining growth of the developed sector in an economy.

S M Sazid Raihan

School of Business, North South University

Dhaka, Bangladesh

Md. Rabiul Islam Rabi

Research Associate, Lead to Live Foundation

Dhaka, Bangladesh

S M Saleh Reza

Faculty, Daffodil International University

Dhaka, Bangladesh
However, it is essential to analyze whether the developed and industrial sectors are equivalent or any other nonindustrial sectors can become the powerhouse economic development by appropriately utilizing the surplus labor.

Examination of statistical trend suggests that the countries attaining successful economic development in the last fifty years, such as South Korea, Taiwan, Malaysia, had done it specifically through development in their industrial sector and service sector as well to some extent [1]. However, it should also be considered that availability and distribution of resources is not the same in all countries, hence the same formula might not be applicable to all developing economies round the world [2].

\section{Inefficiency of Unemployment measurement in Bangladesh}

There are few realistic implications related to employment survey data are needed to be considered before analyzing the overall unemployment situation of Bangladesh. First of all, only those people are considered as unemployed in the survey programs who did not work for at least an hour in previous week and actively searched for employment. The major drawback regarding this methodology is, when a person lives in dire poverty, it is unlikely that s/he would not work for at least an hour in a week. In many occasions, it is observed that people living in poverty may settle with an employment that offers a significantly lower wage rate than the market. Such workers are considered as underemployed [3]. However, underemployment is not reflected separately in the existing labor market data available for analysis in Bangladesh, as they are treated as employed. Hence, the stipulated of unemployment often tends to understate the realistic scenario. It is imperative for the policy makers to overcome the inefficiencies associated with the measurement technics because without the appropriate picture and intensity of the unemployment problem, it would be difficult to devise the most appropriate solution.

\section{Trends in Labor Force and Employment}

If the current scenario of the utilization of surplus labor in Bangladesh's economy is analyzed carefully, few specific trends can be identified from the statistical data related to the Bangladeshi labor force and unemployment scenario across various sectors [3]. Firstly, if the employment growth 
rate is compared with GDP growth rate, the employment growth rate was somewhat lower during the year 2005 to 2010 than the previous five years [2]. The pattern implies that the creation of employment due to growth of production had little impact on the long term improvement on the overall unemployment situation.

Secondly, industrial sectors had been able to generate employment at a higher rate than the farm-sectors, which is indeed a positive matter for the economy[1]. However, it would have been better and more effective if the growth of production from the industrial sectors could have reached double digit at least. Empirical evidence from similar developing economies suggest that to attain a sustainable growth rate of employment creation, it is essential to achieve a minimum of ten percent growth rate in the industrial sectors, especially if the surplus labor has to be utilized through it.

Thirdly, construction industry had been able to generate more employment during the period of 2005 to 2010 than the previous five years compared to the rate of growth in production [4]. The trend implies that productivity of workers had declined in construction sector, which should not have been the case because it is not appropriate in the long term to increase employment through reduced productivity [3].

Fourthly, service sectors have traditionally been considered as labor-intensive industry, hence there should normally be a proportional relationship between the growth of production and the growth of employment in the sector, and that was exactly what happened the period 1995 to 2005 . However, during 2005 to 2010, surprisingly the relationship reversed. In spite of increase in production from the service sector, growth of employment due to growth of production in this sector declined rapidly to almost one-third of the previous period [1]. Although there is no straight forward explanation to such change, however, one possible reason could be the existence of few investment-intensive industries within the service sector. The growth of overall production could come from those specific investment-intensive industries, where labor productivity is very high compared to any other industries.

Bangladesh has already been able to effectively develop some industries including the highly labor-intensive readymade garment industry, providing employment to a large portion of the country's abundant labor force. Although there is a great deal of growth opportunity in the readymade garment sector, however, that might not be sufficient for providing employment to such an increasing number of labor force of the country [5]. Taking this practical scenario into consideration, it is now crucial to identify the opportunities from the non-farm sectors in rural economy. Practicality has to be analyzed appropriately and critically before implementing any policy decisions. It is also essential to compare productivity and earnings of the sectors outside farm and modern industries.

\section{Iv. Rural Economy, Non-farm Sector and Self-Employment}

A careful examination of the rural employment structure in the first decade of this millennia suggests that there has been little changes in the non-farm sectors of the rural economy [11], and agriculture is still the main source of income for people living in the rural area [15]. Data from 2005-06 suggests that at least four non-farm sectors such as fisheries, financial services, education and health \& social services had significantly lower wage rate than agro-based sectors in rural economy [1]. It is highly probable that people employed in these non-farm sectors have no available alternatives. It is also probable that people employed in the agricultural sector are also participating in the non-farm sectors as an opportunity for additional income. A major reason behind the transition of rural population to non-farm sector from agro-based sector is overall improvement of the human capital due to higher educational attainment [15].

Apart from the previously mentioned four sectors, there are also five sectors that offer up to thirty percent higher wage rate than agriculture. Those sectors are mining works, industry, business, government service and social services. However, if these sectors have to be promoted as alternatives to agricultural sectors, it is important to ensure stable growth of productivity, earning and wage in these sectors.

A large portion of Bangladesh's total labor force is selfemployed, hence the income from this segment of the laborforce is a key indicator of the growth of non-farm sectors. Again, data from 2005-06 suggests that self-employed people employed in the service sectors registered a lower earnings than those who are employed in the agricultural sectors. However, Industry, business and transportation sectors enjoyed a slightly higher earnings than agriculture [6]. The data clearly indicates that employment in those sectors are mostly due to lack of available alternatives apart from agriculture and hence does not account for economic dynamism and growth.

Statistical evidence also suggests that although selfemployment has largely been concentrated within the agricultural sector, however, in recent years, there has been a shift to the non-farm sector. Particularly for women, nonfarm self-employment has increased dramatically as a result of increased opportunities contributed by the advancement of information technology, mobile banking facilities and also higher level accessibility to educational and vocational training. Access to micro-credit and stable growth of RMG sector have made a positive contribution toward this scenario as well [16].

\section{v. Labor Migration, Human Trafficking and Remittance}

Apart from the traditional sectors of the internal economy, Bangladesh has also been capitalizing on the rapid growth of remittance, particularly for the last two decades [2]. Remittance sent by the Bangladeshi workers employed in foreign countries have now become a major source of foreign currency in Bangladesh's economy [8]. Statistical evidence suggests that the number of people going abroad for work has become doubled in the year 2013 from the year 2000 [11]. However, there are few important issues to address and analyze before judging the effectiveness of the 
remittance and foreign employment on the national economy.

Firstly, the number of workers going abroad for employment fluctuates from year to year depending on factors, which are often beyond the control of Bangladesh [14]. Bangladesh government may not be able to influence factors including turbulent political situation in the middle-east, or global economic crisis that may put negative impact on the remittance.

Secondly, the migrating workers do not often get their required supports in both and abroad, and often become subject to harassment of various kinds from the immigration related offices. Bangladesh government has obtained a bad reputation in this segment in recent years with its failure to provide consistent and required support to the migrating workers.

Thirdly, most of the workers who intend to migrate to abroad are not properly educated and trained, as they go mainly as non-skilled or semi-skilled workers, because of which they often have to remain content with low wage and very little employment benefits. The overall image of Bangladesh to foreign recruiters also suffers due to this unfortunate reason, and skilled workers from Bangladesh who are highly skilled and educated often may feel demoralized about migration.

Lastly but not the least, right now one of the most important issue that the Bangladeshi policy makers should address is the human trafficking from Bangladesh [17]. Out of sheer desperation as they failed to find any suitable work to support their families, hundreds of people from Bangladesh have recently been rescued while trying to travel to nearby countries including Malaysia and Thailand by boat. This dire situation of refugee migrant crisis have now raised attention from all the world, as South-east Asia has become a grooming ground for human-traffickers. This indicates a severe lack of available income opportunities, particularly in the rural areas of Bangladesh.

Since the remittance earning has already become a prominent source of the currency in Bangladesh, it is high time the government authorities put their close attention to overcome these challenges for structural improvement of this sector [9].

\section{vi. Conclusion}

Despite the fact that foreign migration could be an effective way of employment for the local labor force, it may not be wise to consider it as an alternative to create employment in the local economy. Statistically, each year the labor force of Bangladesh increases by an amount of approximately 2.1 million, and about five to six hundred thousand people migrate as workers to foreign economies. Hence, it is imperative to create new employment opportunities in the country for a sustained growth and development.
It has been found out through analysis of economic trends that to create sufficient employment opportunities for all of the surplus labor force, there must be sustained GDP growth rate of 6.5 percent per annum [2]. However, it is not enough just to create employment for those who are unemployed right now, rather it is also important to create appropriate employment for those who are underemployed, because official economic surveys in Bangladesh often have a tendency to understate the actual unemployment due to its methodological inefficiencies.

Considering the circumstances, if the participation of industrial sector on the overall GDP growth can be increased, it will be possible to provide employment opportunities to a large portion of the surplus labor force. For this purpose, apart from ready-garments, few other industrial sectors such as shoe and leather goods, electronics, furniture, utensils will have to be promoted to create sufficient employment. If the annual growth of those modern industrial sectors can be increased up to 12 to 13 percent, it will create at least six hundred thousands more or employment per annum for the economy and the entire economic infrastructure will be beneficial through such achievement.

\section{References}

[1] Islam, R. (2008). Has Development and Employment through Labour Intensive Industrialization Become History?

[2] Islam, R. (2015). Unnoyon Bhabnay Kormosongsthan O Shromobazar. Dhaka, Bangladesh: The University Press Limited

[3] BBS (2011) Report of the Labor Force Survey

[4] BER (2014). Bangladesh Economic Review 2014. Ministry of Finance, Dhaka.

[5] BBS (2010) Report on Bangladesh Survey of Manufacturing Industries (SMI) 2005-2006

[6] Hasnat, D. R. (2015, March). The Daily Star . Retrieved July 15, 2015, from The Daily Star Website: http://www.thedailystar.net/supplements/24th-anniversary-the-dailystar-part-1/the-future-rmg-trade-73288

[7] Islam, Rizwanul (1990): "Rural Poverty, Growth and Macroeconomic Policies: The Asian Experience". International Labour Review, Vol. 129, No. 6.

[8] Raihan, S. (2015, May 09). Is it a sustained driver of economic growth and employment creation? Retrieved July 15, 2015, from The Daily Star Website: http://www.thedailystar.net/op-ed/economics/itsustained-driver-economic-growth-and-employment-creation-81206

[9] Khan, S. A. (2015). The daily star. Retrieved July 15, 2015, from The daily star website: http://www.thedailystar.net/op-ed/politics/thefuture-remittance-flows-109021

[10] Islam, Rizwanul (2001): "Poverty Alleviation, Employment and Labour Market: Lessons from the Asian sexperience and Policies". Paper presented at the Asia and Pacific Forum on Poverty organized by the Asian Development Bank, Manila, 5-9 February 2001.

[11] Islam, Rizwanul (2003): "Labour Market Policies, Economic Growth and Poverty Reduction: Lessons and Non-lessons from the Comparative Experience of East, South-East and South Asia". Issues in Employment and Poverty Discussion Paper 8, Recovery and Reconstruction Department, ILO, Geneva.

[12] World Bank Group (Ed.). (2014). World development indicators 2012. World Bank Publications.

[13] Osmani, S.R. (2002): "Exploring the Employment Nexus: Topics in Employment and Poverty". (Mimeo) UNDP, New York and ILO, Geneva. M. Young, The Technical Writer's Handbook. Mill Valley, CA: University Science, 1989.

[14] World Bank Group (Ed.). (2012). World development indicators 2012. World Bank Publications. 
[15] Bureau of Manpower, Employment and Training (BMET), website: http://www.bmet.org.bd

[16] Hossain, M. (2015, March 12). Drivers of the rural economy. The Daily Star. Retrieved June 30, 2015, from http://www.thedailystar.net/supplements/24th-anniversary-the-dailystar-part-3/drivers-the-rural-economy-71114

[17] Basak, J. (2013). Dynamics of Labor Force. In R. Titumir (Ed.), Accumulation and Alienation: State of Labour in Bangladesh 2013. Dhaka: Shrabon Prokashani.

[18] Azad, A. (2015, July 12). A security crisis in the making? The Dhaka Tribune. Retrieved July 20, 2015, from http://www.dhakatribune.com/bangladesh/2015/jul/12/security-crisismaking

About Author (s):

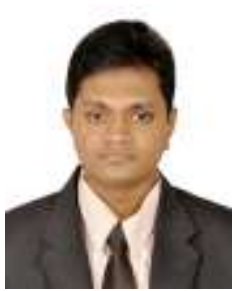

S M Sazid Raihan is currently pursuing his Masters in Business Administration, with a major in Human Resources Management, in North South University. He has obtained his Bachelors in Business Administration from North South University. His research interests are human resource management, entrepreneurship and organizational management.

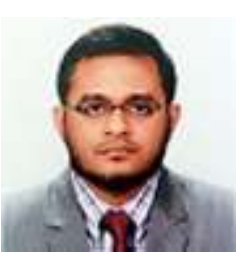

S M Saleh Reza is currently teaching at Daffodil International University. He has completed his MBA with a major in Human Resources Management from North South University, Bangladesh. $\mathrm{He}$ is also a $\mathrm{PhD}$ researcher at Bangladesh University of Professionals.

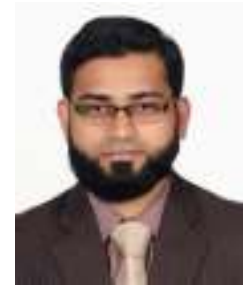

Md. Rabiul Islam Rabi has completed his Masters and Bachelors in Social Science in Economics from Department of Economics, University of Dhaka. His research interest focuses on human capital, economic growth, labor economics and moral philosophy. 